\title{
Equity of Access to Higher Education in the Context of South-South Cooperation in Latin America: a pluri-scalar analysis
}

\author{
Thomas Muhr \\ Address for correspondence: \\ University of Nottingham, School of Education, Jubilee Campus, Wollaton Road, Nottingham \\ NG8 1BB, United Kingdom \\ Thomas.Muhr@nottingham.ac.uk
}

\begin{abstract}
This article draws from an education governance approach to conduct a pluriscalar analysis of equity of access to tertiary education in the context of South-South cooperation. An account of distributional justice in access to tertiary education in the Federative Republic of Brazil and the Bolivarian Republic of Venezuela is integrated with a structural approach related to South-South cooperation among the two nations as well as within the Southern Common Market (MERCOSUR), upon which two interrelated arguments are developed: first, despite persistent inequities in access to university education in both territories, state-interventionist policies enhance equity of access directly with respect to availability and accessibility. Second, South-South cooperation transforms the background conditions for educational justice by producing an alternative structure to the neoliberal global governance of education and its agenda of privatisation and commercialisation.
\end{abstract}

\section{Keywords}

Brazil; higher education; education governance; equity; international cooperation; MERCOSUR; social justice; South-South cooperation; Venezuela

\section{Introduction}

In his elaboration of three dimensions of equity of (or equal opportunity in) access to higher education - availability, accessibility and horizontality_-Tristan McCowan concludes on a discouraging prognosis for 'the upholding' of these principles in the context of the progressing privatisation and marketisation of tertiary education globally (McCowan 2015, p. 17). ${ }^{1}$ Even university education expansion, McCowan

\footnotetext{
${ }^{1}$ I generally follow the Venezuelan government in using university rather than higher education, as the latter suggests a hierarchisation that is incompatible with an integral approach to education that views all levels and modalities of education as complementary and equally important to individual and collective (social) development. Throughout the text, 'university education' is used interchangeably
} 
shows, can be accompanied by an exacerbation of inequalities. However, by reference, inter alia, to the Brazilian government's higher education policies, McCowan also indicates possibilities for a more equitable (fairer) higher education landscape. By building on these discussions, this article integrates an account of distributional justice in access to tertiary education in the Federative Republic of Brazil and the Bolivarian Republic of Venezuela with a structural approach related to South-South cooperation among the two nations as well as within the Southern Common Market (MERCOSUR), upon which two interrelated arguments are developed: first, despite persistent inequities in access to university education in both territories, state-interventionist policies enhance equity of access directly with respect to availability and accessibility. Second, South-South cooperation transforms the background conditions for educational justice by producing an alternative structure to the neoliberal global governance of education and its agenda of privatisation and commercialisation.

Methodologically, an education governance approach permits analysis at and across different scales of policy-making processes, while it recognises that economic and political projects may not be organised and constructed by state actors alone (Dale 1997, 2005; Robertson and Dale 2013). For the purpose of this analysis of equity of access to university education, however, the benefit of the education governance approach principally consists in its heuristic value of a pluri-scalar analysis rather than in examining the roles of non-state actors in governance activities. The concept of 'scale' is borrowed from human geography, where 'scale' has been theorised as socially produced through institutionalised sets of practices and discourses (e.g., Paasi 2004, p. 537). While the production of scale is "integral to" the production of space (Marston and Smith 2001, p. 616), which is of lesser relevance to the discussions in this article, categorisations of scale include: the body, household and other local and sub-national (e.g. community; municipal government), national (e.g. nation-state governments), inter- and transnational (e.g. cross-border regionalisms; transnational communities), regional (supranational regionalisms) and global (e.g. finance flows) scales (Brenner 2004; Mansfield 2005; Marston and Smith 2001; Smith 1992). In contrast to 'level', and its association with a fixed hierarchical arrangement (as in 'levels of government'), scalar configurations are perpetually (re)constituted and redefined through social praxis, 'in terms of their extent, content, relative importance, and interrelations' (Swyngedouw 1997, p. 141; also, Howitt 1993, 1998). With respect to this pluriscalar approach to educational justice, two distinct scales of university education governance have been produced through South-South cooperation, besides the inter-national (i.e., between the national governments): a regional scale, through the South-South cooperation dimension in MERCOSUR, of which both Brazil and Venezuela are full members; and a Northern Brazilian/Southern Venezuelan inter-municipal, transnational cross-border scale termed 'Special Border Regime'.

Subsequently, this analysis unfolds at the following interrelated scales of governance: at the national scales, the Brazilian and Venezuelan governments' policies of expanding university education are examined through the lens of availability, accessibility and horizontality. A schematic discussion of both governments' tertiary education policies implemented between the late 1990s and 2015 concentrates on the 
access-related quantitative dimension as expressed in enrolment figures, thus ignoring qualitative aspects as well as politico-philosophical/ideological and political economic motives for expanding access. At the regional MERCOSUR scale structural 'background conditions' for educational justice (Robertson and Dale 2013, p. 428) are sketched out. At the inter-municipal cross-border scale, increased access to university education in the Special Border Regime is explored. Empirically, the discussion is based on contents and discourse analysis of 81 cooperation documents signed among Brazilian and Venezuelan state and non-state actors since 2003, municipal, national and regional development plans, and 1 month of field research in the emerging Special Border Regime in 2012. Participant observation and 13 semi-structured, openended interviews were conducted with officials at different levels of the policymaking processes, academics at the Bolivarian University of Venezuela (UBV) Ciudad Bolívar, as well as local scale actors in distinct cooperation and integration initiatives on both sides of the Brazil/Venezuela border.

\section{Education governance, South-South cooperation and equity of access to tertiary education}

For Dale (1997, 2005), contemporary (neoliberal) education governance can be broken down into four specific 'sets of activities' or 'mechanisms' that are not necessarily all performed by the state but also by non-state actors (market; community; household), together with or independent of the state: funding; regulation (control); provision (delivery); and ownership. Combinations of funding and regulation, Dale continues, provide the 'framework' for 'educational policy, provision, and practice' (1997, p. 277). These activities are not necessarily located at the national scale, but may also 'occur' at sub- and supranational scales. Thus, in contrast to a comparative study_-'learning from comparing' and 'explaining through comparing' based on the assumption of isolated, autonomous and heterogeneous national education sectors and systems (Dale 2005) - a relational, pluriscalar approach permits to structure an analysis of equity policies at different, interrelated scales of governance. Therefore, as stated previously, for the purposes of this study of educational justice through the creation of an alternative South-South (counter-) structure to the neoliberal global governance of tertiary education, the governance approach here serves as a heuristic device for analysing equity-enhancing state policies at and across different scales, rather than examining the inter-scalar sectoral and functional 'division of the labour of educational governance' (Dale 2005, p. 132) [i.e. the roles of such actors as households, communities and private (market) providers therein]. That is, while the existence of private tertiary education sectors in both territories as part of the neoliberal global education governance regime is recognised, they (and their internal dynamics) are not part of this analysis of an equity-enhancing state-interventionist counter-governance regime.

The argument for a pluri-scalar approach to educational justice is that the respective policies and practices, that is, their 'form, pattern and scope', are shaped by the 'structures, processes and practices of education governance frameworks' (Robertson and Dale 2013, pp. 426-427). In other words, as essential as distributional accounts of educational (in)justice are, these are incomplete without a 'relational account of 
justice' (Robertson and Dale 2013, p. 427), in order to also consider the structural conditions that underlie or produce distributional injustice. It is hereby important to recognise that 'education governance frameworks are also mediated by political projects' and that the ideologies that underpin political projects need to be made explicit when discussing educational justice:

Current forms of privatising in and of all aspects (not just funding) of education governance, and in the globalising of education as services sector, are connected by a common political project - that of neo-liberalism... In short, the manifestations of privatisation are the outcomes of power and competing projects. (Robertson and Dale 2013, pp. 431, 433, italics in original)

The three subsections that follow integrate an analysis of the three principles of equity of access to tertiary education (availability, accessibility, horizontality) at the national scale with a structuralist approach to social transformation through South-South cooperation at the international, regional and inter-municipal cross-border scales of governance. These policies, processes and practices are inseparable from the stateinterventionist development strategies implemented in Venezuela since 1999 (with the first Chávez presidency) and in Brazil from 2003 on (with the first Lula da Silva presidency). Referred to as neostructuralist 'endogenous development', this pursues, inter alia, the repayment of the 'social debt' (Sunkel 1993) including, as the Brazilian government states, the 'educational debt' (Federative Republic of Brazil 2007b, p. 9; also, Federative Republic of Brazil 2007a; MINCI 2004). While the Venezuelan university education policies confront neoliberalism within the national project of constructing socialism (e.g. Duffy 2014; González Silva 2009; Griffiths 2013; Muhr 2010, 2011; Muhr and Verger 2006), in Brazil the policies of the past 10 years have emphasised 'equity', 'solidarity' and 'the need to structurally challenge the inequalities of educational opportunity’ (Federative Republic of Brazil 2007b, p. 6). These neostructuralist development policies have been 'upscaled' from the national to inter-, trans- and supranational scales in the form of South-South cooperation. This constitutes a resurgence of the post-World War II idea and practice of South-South cooperation as Third World emancipation, decolonisation and collective self-reliance, and such policies have (in Latin America-Caribbean) since the 2000s also been promoted by MERCOSUR members Argentina and Uruguay, alongside other states such as the Republic of Ecuador and, over the past 50 years, the Republic of Cuba (see: Ayllón and Ojeda 2013; Ayllón et al. 2014; Muhr 2015a, b, 2016a; Sá e Silva 2009). Governed by the principles of 'solidarity', 'complementation' and 'cooperation', established as such by the 1967 Group of 77 (G-77) Charter of Algiers, South-South cooperation is associated with 'equal and reciprocal relationships with other developing countries', 'non-interference' and avoidance of 'political conditionality' (UNESCO 2014, p. 49). Thus, as will further be discussed below, from 2003 on these principles of South-South cooperation became integrated in the Southern Common Market (MERCOSUR). Concomitantly, also from 2003 on, bilateral South-South cooperation between the governments of Brazil and Venezuela was initiated and became consolidated as 'strategic alliance' in 2005 (Bolivarian Republic of Venezuela/Federative Republic of Brazil 2005). As is explored in greater detail elsewhere (Muhr 2013, 2016b), by 2008 the principles of solidarity, complementarity and cooperation became internalised in the bilateral cooperation 
discourse and practices, as about 200 cooperation agreements have been signed since 2003 between the national governments and state institutions as well as sub-national scale state and non-state actors and social forces. With respect to education, this cooperation agenda envisions the 'universalisation of higher education', whereby 'solidarity cooperation and complementarity' among the tertiary education systems specifies academic mobility, joint study centres and programmes, under- and postgraduate courses, doctoral studies and research programmes in the mutual interest, as well as the creation of academic, publishing and dissemination networks, the recognition of academic credits and titles, and the mutual exemption from any charges raised by state institutions (Bolivarian Republic of Venezuela/Federative Republic of Brazil 2008a, b, c, d, e). Joint equity aspirations are mirrored in the pursuit of 'strengthening public [i.e., state] education accessible for all sectors of the population' (Bolivarian Republic of Venezuela/Federative Republic of Brazil 2008d, Point 19).

\section{The national scales: availability, accessibility, horizontality}

McCowan (2015) characterises the three principles of equity of access to tertiary education as follows: availability refers to the overall capacity (places and 'adequate' infrastructure and teaching staff) to accommodate all of those who both want to study and fulfil the minimum academic requirements. Subsequently, fairness in accessibility depends upon the removal of possible barriers to access, especially fees (including different levels of fees within in a system) and entry examinations (which discriminate against those with low quality pre-university education), as well as geographical location of institutions, opportunity costs (foregone earnings), and other constraints related to class, race and ethnicity (culture, language, identity). Finally, horizontality means 'even prestige and quality across the system', especially concerning the value (recognition) of degrees within society and the associated 'positional advantages' through stratification (lower classes generally being confined to less prestigious universities). With respect to Brazil and Venezuela, availability has over the past 10-15 years been increased in both contexts: in Brazil, gross enrolment has risen from $14 \%$ in 1999 (UIS 2010) to $16.6 \%$ in 2003 and $28.7 \%$ in 2013 (INEP 2013); in Venezuela, from $28 \%$ in 2000 to $79 \%$ in 2008 (UIS 2010) and $82.2 \%$ in 2014 (MPPEU 2015, p. 11).

In both nations, public (i.e. state financed) universities are free of charge, and in neither has (for profit/not-for-profit) private provision and the university education market been outlawed. The strategies for expansion adopted, however, differ fundamentally. In Venezuela, based on the constitutional right to free state-provided university education introduced in 1999, measures to reduce barriers to access have from 2003 on included the creation of the Bolivarian University of Venezuela (UBV) alongside several 'missions' (misiones) (Muhr and Verger 2006). These are statefinanced foundations that differ from conventional assistentialist or compensatory welfare schemes by combining immediate poverty alleviation with long-term structural transformation, and over the past 10 years 42 of these programmes have been operating in a complementary fashion across strategic socio-economic, sociocultural and sociopolitical sectors 
(http://www.gobiernoenlinea.ve/home/misiones.dot\#, accessed 2 October 2015; Muhr 2011, pp. 123-127). Out of eight missions related to formal and non-formal education at the different levels, Misión Alma Mater has involved the transformation of 29 state-financed university institutes and colleges into national experimental universities alongside the creation of over 30 new universities across the territory, while UBV and Misión Sucre epitomise the 'municipalisation' of university education via a satellite structure composed of eight regional UBV headquarters and associated 'university villages' (aldeas universitarias, henceforth aldeas; Muhr and Verger 2006; Muhr 2010, 2011, pp. 150-155; also see MPPEU 2015, pp. 12-14). In contrast to 'university city' or 'campus', which usually are geographically isolated and associated with a single university or perhaps different universities that offer individually administered programmes, aldea as originally conceptualised by the Office for the Planning of the University Sector (Oficina de Planificación del Sector Universitario, OPSU) embodies the pooling of the teaching and research capacities of different tertiary education institutions for the development of joint academic programmes. Within OPSU's Alma Mater Project for the Improvement of the Quality and Equity of University Education in Venezuela (Proyecto Alma Mater para el Mejoramiento de la Calidad y Equidad de la Educación Universitaria en Venezuela), initiated in 2001, the participating universities would be users (rather than owners) of the facilities provided by the state-administered aldea (e.g. classrooms, library, laboratory, offices; Toro 2004). In the course of municipalisation, however, aldea came to mean simply a municipal branch of Misión Sucre/UBV.

In 2013, 1.308 such aldeas were operating in educational institutions, prisons, military garrisons and libraries in all 335 municipalities (MPPEU 2014, pp. 2305-2306). Thus, as the subsection on the Special Border Regime will underscore, university education is taken to 'where the people live', while 'epistemic access' ('meaningful access to the curriculum', McCowan 2015, p. 7) is improved through linguistic and cultural adaptation to local contexts and a free-of-charge preparatory Misión Sucre programme called 'Initial Semester' (Semestre or Trayecto Inicial; Muhr 2011, p. 157; MPPEU 2014, p. 2305; also see Toro et al. 2009). Moreover, 'criterion-based' affirmative action, which 'challenges the supposedly meritocratic basis of admissions procedures' (especially those of elite institutions) (McCowan 2015, pp. 6, 16), has involved: first, entry examinations, which in Venezuela had been found as structurally discriminating (Muhr 2011, p. 151; also Griffiths 2013, pp. 98-100), were outlawed in 2008 and replaced by a 'multivariable' quota system that considers, inter alia, academic grade, socio-economic conditions and territoriality (Muhr 2011, pp. 156157; MPPEU 2015, p. 14; OPSU 2015). Quota systems also ensure access for people with a disability, as well as the allocation of Misión Sucre students in the more prestigious established state-funded universities (González Silva 2009, pp. 171-172; Muhr 2011, p. 157). Second, such measures as free public student transport for UBV students and a targeted grant system have been introduced (216,965 grant recipients in 2014 out of a total student population of 2,620,013, MPPEU 2015), which has further involved converting previously awarded loans into grants in 2003 (González Silva 2009 , p. 169). Finally, based on the recognition that the determination of educational life chances starts at birth, efforts of universalising pre-primary education has included a state-driven increase in infant education gross enrolment from $45 \%$ in 1999 to $76 \%$ in 2013 (UIS 2015a). 
In contrast, expansion of availability of tertiary education in Brazil is strongly associated with marketisation and increased private sector involvement, initiated by the neoliberal Cardoso government (1995-2002) via Law no. 9.394 (20, December 1996), Decree no. 2.306 (17 August 1997) and Decree no. 2.207 (15 April 1997) (Azevedo 2015a; also Sobrinho and Ferreira de Brito 2009). From 2003 on, however, the state sector has been strengthened through recomposing and increasing the public sector budget, the creation of 14 new state universities and over 50 campuses linked to existing federal universities, as well as 78 new federal professional and technical colleges via the Federal University Support Programme for Restructuring and Expansion (REUNI) (Federative Republic of Brazil 2007b, pp. 27-28; Gomes et al. 2014, pp. 175-77). Expansion of availability has been accompanied by affirmative action through state regulation in support of equity in accessibility: first, the introduction of a quota system to reduce the historical class and race (and race-class) discrimination in access to the more prestigious public universities (McCowan 2007, 2015; dos Santos 2014). As in Venezuela, such segregation is largely rooted in entry examinations that privilege those who can afford high-quality private secondary schools and preparatory courses (McCowan 2015). Accordingly, as of 2012, Law 12.711 obliges federal (public) universities (as well as medium technical institutes) to allocate $50 \%$ of places to low-income public secondary school leavers, of which students of black, indigenous and mixed descent must constitute a proportion no less than their relative population within the federal state in which the institution is located (Presidência da República 2012, Article 1). ${ }^{2}$ Second, the 'University for All Programme' (Programa Universidade para Todos, ProUni) provides targeted household income-dependent scholarships for undergraduate study at private universities, whereby students coming from public secondary schools are eligible as well as those low-income students who had already received a full scholarship for study in private secondary schools (Presidência da República 2005, Articles 1, 2). This means that self-funded private secondary school graduates are excluded from receiving such university scholarships. Third, the new National Secondary School Exam (Exame Nacional do Ensino Médio, ENEM) seeks to achieve a fairer distribution of university places and scholarships (Federative Republic of Brazil 2007b, p. 29; McCowan 2015, p. 17; Presidência da República 2005, Article 3). Finally, as in Venezuela, the Law of the National Education Plan recognises the importance of pre-primary education by aiming to universalise infant education for the 4- to 5-year-olds by 2016 (Presidência da República 2014, Annex).

Despite the stated actions and achievements, horizontality remains an ideal in both systems. High stratification prevails, albeit in slightly different forms. In Venezuela, deprivatisation has reduced private sector enrolment from $43.6 \%$ (2000) to $28.8 \%$ (2010) (UIS 2015b) and $23 \%$ in 2012 (as compared to $65 \%$ public and $12 \%$ autonomous) (MPPEU 2012). In 2014, 1.965 .449 out of 2.620 .013 students were enrolled in public institutions (MPPEU 2015, p. 12), equating a public enrolment ratio of $75 \%$. While this may suggest that the state-funded sector has been gaining in prestige, however, this itself is characterised by 'inclusion with segregation' (Muhr and Verger 2006, p. 180), or stratified inclusion, as the historically excluded popular classes overwhelmingly participate in the newly created, less prestigious state

\footnotetext{
2 'Federal' refers to 'national', in contradistinction to (federal) state and municipal institutions. During the first four years of coming into effect, the law demands a minimum quota of $25 \%$ (rather than 50 \%) only (Presidência da República 2012 Article. 8).
} 
university education circuits (UBV and the missions). However, the extent to which and/or in what respects this may generate positional disadvantages in the current context of revolutionary transformation would require specific research that does not appear to be available at this moment. With respect to Brazil, there is general agreement that 'the high correlation between studying at a public university and achieving positions of prestige, power, and authority' in Brazilian society (dos Santos 2014 , p. 153) is the product of 'highly differentiated public and private sectors...with access to institutions of quality or prestige for the most part restricted to the upperincome groups' (McCowan 2015, pp. 11, 13). There, private enrolment incremented from $63.1 \%$ in 1999 to $74 \%$ in 2013 (INEP 2013).

In both Brazil and Venezuela, therefore, (re)regulation through law-based affirmative action and direct state funding of public institutions deprivatises and demarketises tertiary education. Further examples of such practices include curbing (in the Brazilian government's words) the 'chaotic expansion' of the private sector, such as through the regulation (but not abolishment) of tax exemptions granted by preceding neoliberal administrations (Federative Republic of Brazil 2007b, pp. 27-29; Presidência da República 2005, Article 8), and the aim of increasing tertiary education gross enrolment to $50 \%$ by 2024 , with a share of $40 \%$ of new enrolments in the public sector (Presidência da República 2014, Annex). The following subsection extends the analysis to the regional scale to explore structural 'background conditions for social justice' (Robertson and Dale 2013, p. 428), before turning to the inter-municipal cross-border scale as a manifestation of the intertwinedness, or interrelatedness, of 'the national' and 'the regional'.

\section{The regional scale: MERCOSUR as an education governance regime}

MERCOSUR was founded in 1991 by the neoliberal governments of the Argentine Republic, Federative Republic of Brazil, Eastern Republic of Uruguay and the Republic of Paraguay. The Bolivarian Republic of Venezuela and the Plurinational State of Bolivia joined as full members in 2006 and 2012, respectively (Bolivian membership is in the process of ratification at the time of writing). Even though the Venezuelan full membership was ratified in 2012 only, from 2006 on Venezuela transcended the status of associate member and contributed to shaping MERCOSUR policy-making, for instance, through participation in such meetings as the 32nd Meeting of the Education Ministers (MERCOSUR 2007). From 2003 on, driven by inter alia the Brazilian and Venezuelan governments, a 'paradigm shift' in MERCOSUR has sought a transformation from 'just a [neoliberal] free trade agreement' to a 'social and compassionate economy' in which 'the social and productive dimensions complement trade' (Briceño Ruiz 2012, p. 175). With the objective of 'overcoming neoliberalism' (MERCOSUR 2006, Point 3), this is manifest in the adoption of the South-South cooperation principles of 'solidarity', 'complementarity' (related to the creation of productive synergies) and 'cooperation' (with respect to production, technology and knowledge transfer; e.g. MERCOSUR 2012a, b, c). Importantly, public policies, including education, are identified as central to reducing the 'severe social, economic, productive and commercial asymmetries, contain the rural exodus (of especially young people), [and] restrain contraband and 
labour exploitation' in the historically marginalised border zones, such as the Southern Venezuelan/Northern Brazilian (Instituto Social del MERCOSUR 2015; also see: Federative Republic of Brazil 2007a, p. 15, b, p. 37; Ferraro 2013; MERCOSUR 2012a, pp. 45-68; Presidência da República 2003, pp. 7-8, 2007; RBV 2001, p. 93, 2007).

Consecutive MERCOSUR Education Sector Plans (Sector Educativo del MERCOSUR SEM) echo and reinforce these shifts. Although the fundamental strategic objectives laid out in the different plans have not essentially changed over time, the principle of 'solidarity cooperation' (MERCOSUR 2000: 4) became specified and consolidated (MERCOSUR 2005, p. 13, 2011, p. 11) as 'profound structural change' has been called for (MERCOSUR 2005, p. 5). The purpose of education for 'competitiveness' (MERCOSUR 2000, p. 2) has been removed from the 2005 and 2011 Plans, and neoliberal 'human resources' formation (MERCOSUR 2000, p. 4) has become superseded by 'human development' (MERCOSUR 2005, p. 10, 2011, p. 13). In this course, education became reclaimed as a 'human right and public and social good' (MERCOSUR 2011, p. 4). Importantly, while the 2000 Plan follows the hegemonic 'education for all' agenda by narrowly focusing on formal education and restricting the right to education to 'basic education' (primary and secondary or 'medium'; MERCOSUR 2000, p. 4), the subsequent Plans also consider modalities such as adult and non-formal education (MERCOSUR 2005, p. 11). As in the Brazilian and Venezuelan national policies, a 'democratisation' of tertiary education at the undergraduate level is pursued (MERCOSUR 2011, p. 46), however, also through private sector involvement (MERCOSUR 2011, p. 67).

While there do not appear to exist policies within MERCOSUR that directly address educational (in)justice, the outlined political shift, while principally originating at the national (member state) scales, has in return changed the context for education policy at the national and sub-national scales. By context I mean not simply background or 'detail', but 'those things that environ and thereby define a thing of interest' (Abbott 1997, n. 10). In other words, if MERCOSUR is understood as an education governance regime, a transformation of the structural conditions that underlie or produce distributional injustice is ongoing even though — as in the Brazilian and Venezuelan national contexts - private participation (funding, provision) continues. The following exploration of increased access to university education through crossborder cooperation in the Brazil/Venezuela Special Border Regime illustrates some of the equity outcomes produced through state intervention at and across the different scales.

\section{The inter-municipal scale: increasing equity of access in the Special Border Regime}

Historically, Northern Brazil and Southern Venezuela are underdeveloped areas, socioeconomically characterised by illegal mining and associated problems, especially contraband, drug trafficking, environmental contamination, (child) prostitution and violation of indigenous rights (Martinez 2009). The objective of providing a development alternative while (re)claiming state sovereignty over that 
area entered the official Brazil-Venezuela cooperation agenda in 2004, which led to the establishment of the Special Border Regime between the border towns Pacaraima (Municipality of Pacaraima, Roraima state, Brazil) and Santa Elena de Uairén (Municipality of Gran Sabana, Bolívar state, Venezuela) in 2010 (Bolivarian Republic of Venezuela/Federative Republic of Brazil 2010a, b). ${ }^{3}$ Spatially, however, the subregion extends to Ciudad Bolívar and Puerto Ordaz in the Venezuelan state of Bolívar, and to Boa Vista and Manaus in the Brazilian states of Roraima and Amazonas. This is manifest in a range of development cooperation dimensions: infrastructure projects (a fibre optic connection provided by the Venezuelan state company CANTV and Venezuelan electricity supply to Northern Brazil; road, rail, river and air connections); trade, financial (mutual opening of state banks on both sides of the border), military, industrial (exchange of knowledge, experience and technology in support of small entrepreneurship and biodiversity), security (training of members of Bolívar state police forces in Roraima), and education cooperation. Although many of especially the socio-productive development projects are at the planning stage and/or under construction only, existing initiatives include a binationally managed agricultural research centre; an International Centre for the Attention of Migrant Women operating in both Pacaraima and Santa Elena de Uairén; efforts to legalise dual nationality; a Local Border Card (Cédula Vecinal Fronteriza) that permits the tax-free cross-border flow of subsistence goods purchased for personal consumption in either of the border towns; a cross-border public transport system; and free-of-charge health and education services mutually accessible on either side of the border (Bolivarian Republic of Venezuela/Federative Republic of Brazil 2010a, b). In 2012, school children were crossing the border on a daily basis within the MERCOSUR Twin Border Schools programme, through which schools have became transnationally twinned in the Brazil/Argentine border zone since 2005, the Brazil/Paraguay and Brazil/Uruguay border zones since 2008, and the Brazil/Venezuela border zone from 2009 on. The original mission of providing bilingual and intercultural education has been extended with the MERCOSUR (2011) Education Plan, aiming for these twin schools to become organically embedded within the wider processes of cross-border economic/productive, social and infrastructural integration (Bolivarian Republic of Venezuela/Federative Republic of Brazil 2009; MERCOSUR 2005, 2011, pp. 16, 31-32).

In this context, after just over 1 year of planning and in response to demands by the population and the mayoralty of Gran Sabana, the University Aldea Gran Sabana Roraima Garrison (Aldea Universitaria Gran Sabana Fuerte Roraima) was established in October 2004 inside the barracks of the Bolivarian Armed Forces near Santa Elena de Uairén (Toro 2004). This unusual location inside the garrison is due to the territorial delimitation of Santa Elena de Uairén and Pacaraima by national parks and indigenous lands, which legally restricts geographical expansion and, therefore, border zone development. Today, this aldea is the largest of several in the municipality of Gran Sabana (Venezuela) (Cabrera 2009; UNESCO-IESALC 2008). Moreover, it was the first ever instituted aldea and embodies the original idea of a place in which synergies are generated through the pooling of the teaching and

\footnotetext{
${ }^{3}$ While the Agreement for the Establishment of a Special Border Regime (Bolivarian Republic of Venezuela/Federative Republic of Brazil 2010b) was ratified by the Venezuelan state in 2010, in Brazil this was still in process in 2014 (Bolivarian Republic of Venezuela/Federative Republic of Brazil 2014).
} 
research capacities of six Venezuelan tertiary education institutions in the process of municipalisation. These are Misión Sucre, through which UBV programmes are delivered; the National Experimental Polytechnic University of the Armed Forces (Universidad Nacional Experimental Politécnica de la Fuerza Armada Nacional, UNEFA); the National Experimental University of Guayana (Universidad Nacional Experimental de Guayana, UNEG); the Experimental Liberating Pedagogical University (Universidad Pedagógica Experimental Libertador, UPEL); the National Open University (Universidad Nacional Abierta, UNA); and the National Experimental University Simón Rodríguez (Universidad Nacional Experimental Simón Rodríguez, UNESR). While overlappings with respect to courses offered exist (e.g. courses related to tourism), each of these universities offers distinct areas of expertise, thus complementing each other. For example, UNEFA has offered Agronomy, Nursing, and Tourism; UNEG has provided undergraduate courses in Public Accountancy, Business Administration, Fiscal Sciences, and Tourism; and UBV's expertise includes Environmental Management. In all cases, programmes offered may change over time in accordance with the changing developmental needs of the surrounding communities. In 2012, the aldea had about 800 students attending morning, afternoon, evening and weekend classes and, located close to the local airport, university education is also provided by air to isolated indigenous communities.

Within the general framework of bilateral (Brazil-Venezuela) cooperation and MERCOSUR integration, formal and informal relations have been established between the Venezuelan universities and their public counterparts in Brazil: within an interstate cooperation framework (i.e. the federal states of Bolívar in Venezuela and Amazonas and Roraima in Brazil), agreements have been signed, first, between UNEG and the Federal University of Amazonas (Universidade Federal do Amazonas, UFAM), the Federal University of Roraima (Universidade Federal de Roraima, UFFR) and Roraima State University (Universidade Estadual de Roraima, UERR); and, second, between UBV Bolívar State and UFAM. Mutual student exchange and academic mobility (visiting professors) take place in accordance with the principle of complementarity: Brazilian students from as far away as Manaos and Boa Vista are attracted by courses that are either not offered in their immediate environments or are subject to access restrictions, such as medicine. According to one interviewee, most of the students of the UBV/Misión Sucre National Programme of Integral Community Medicine are Brazilian, come to live in Santa Elena de Uairén and Pacaraima, and some stay on after graduation. Venezuelan students may study Tourism in the Pacaraima branch of Roraima State University, which is supported by placements/internships facilitated by the Boa Vista Tourism Department. Academic mobility includes UNEG staff working in the Pacaraima branch of Roraima State University, joint workshops (knowledge and experience exchange on an annual basis), and language courses.

This cooperation, as limited as it may appear, has meant a significant improvement of people's opportunities of access to tertiary education in the border zone. Prior to the facilitation of education migration through the creation of the Special Border Regime and Venezuela's full membership of MERCOSUR, the geographical asymmetries regarding availability of tertiary education, which have historically characterised both the Brazilian and Venezuelan territories, expressed themselves in various ways. F or 
instance, on the Brazilian side, the socio-economically marginalised North Region of Brazil, to which the states of Amazonas and Roraima belong, has been considered the most disadvantaged nationwide, with only a total of 122 tertiary education institutions (106 private/16 public), as compared to 1051 (953 private/98 public) in the privileged South-East Region of Brazil (Sobrinho and Ferreira de Brito 2009, p. 243). On the Venezuelan side, prior to the establishment of the University Aldea Gran Sabana Roraima Garrison, the closest tertiary education institutions were a (minimum) 5-h bus journey from Santa Elena de Uairén (Toro 2004).

\section{Conclusion: enhancing equity of access to tertiary education through South-South cooperation}

The pluri-scalar analysis conducted in this article has focused on state-interventionist policies designed to increase equity of access to university education at and across three scales of education governance: the national, regional (MERCOSUR) and transnational inter-municipal cross-border scales. In this, the heuristic value of the education governance approach has consisted in introducing the concept of scale as socially produced through institutionalised sets of discourses and practices, in this case through bilateral and regional South-South cooperation. The example of the Special Border Regime, in particular, has served to show how synergies are generated through South-South cooperation and how equity of access to university education is enhanced by improved availability and accessibility. The study also shows how efforts of deprivatisation and demarketisation are intertwined with state policies and strategies of territorial deconcentration and the 'evening out' of uneven development, from the urban centres (where also the private and profitmaking providers tend to be concentrated) to structurally disadvantaged zones and historically marginalised populations. Without doubt, as highlighted, inequities of access persist in both the Brazilian and Venezuelan territories, most glaringly with respect to horizontality, which is not directly addressed by the policies discussed. Whether these policies have any indirect bearing on stratification would have to be subject of further and more specific research that to date does not appear to have been conducted.

The Special Border Regime, however, also illustrates the structural interrelatedness of educational justice with scales of governance other than the national within an emergent pluri-scalar South-South educational governance regime. That is, while the cross-border sub-region emerges as a distinct scale of educational governance- a manifestation of the intertwinedness of 'the national' and 'the regional' - the pluriscalar approach permits to extend the analysis to the structural 'background conditions' that underlie or produce distributional (in)justice in access to tertiary education, especially with respect to accessibility and stratification. It is hereby important to reiterate that 'education governance frameworks are also mediated by political projects' and that the ideologies that underpin political projects need to be included in discussions and analyses of educational justice (Robertson and Dale 2013, p. 431). As has been argued, the principles and practices of South-South cooperation provide such an ideological underpinning. 
In this regard, Azevedo (2015b, c), by drawing from Tünnermann Bernheim, identifies a 'contradiction' between two models of education governance: one related to market-driven transnationalisation; the other one to internationalisation associated with solidarity. In this sense, as Bernheim (2009, pp. 51-52) states, internationalisation...

...works toward increasing international cooperation and is respectful of the idiosyncrasies and identities of the participating countries. It seeks to create networks between universities and expand academic space.... The tools for promoting internationalization include academic networks, common partnerships between universities, horizontal cooperation and the creation of expanded academic spaces.

In contrast, transnationalisation...

...entails the rise of services subject to the rules of the market, where the interests of transnational corporations prevail.... Transnationalization seeks to facilitate the establishment of foreign university subsidiaries in our countries.... It includes the sale of academic licenses and the creation of corporate universities that are sponsored by large, transnational corporations and virtual universities from the developed world.

This simultaneous 'commodification and solidarity' (Azevedo 2015b, p. 26), however, is a manifestation of two conflicting political projects related to distinct ideologies and class interests. Thus, the state-interventionist South-South cooperation as a practice of internationalisation (which, as this study shows, by no means implies per se the absence of transnational relations and processes) challenges neoliberalisation through the social practices, relations and processes of solidarity, complementarity and cooperation. This implies a transformation of the structural 'background conditions' for educational justice, thus enhancing equity in access to tertiary education by building a counter-structure to the neoliberal global governance of education.

\section{References}

Abbott, A. (1997). Of time and space: The contemporary relevance of the Chicago School. Social Forces, 75(4), 1149-1182.

Ayllón, B., \& Ojeda, T. (2013). La cooperación sur-sur y triangular en América Latina. Madrid: Catarata.

Ayllón, B., Ojeda, T., \& Surasky, J. (2014). Cooperación sur-sur: Regionalismos e integración en América Latina. Madrid: Catarata. 
Thomas Muhr (2016) Higher Education. The International Journal of Higher Education Research doi: $10.1007 /$ s10734-016-0017-9

The final publication is available at http://link.springer.com/article/10.1007/s10734-016-0017-9

Azevedo, M. L. N. (2015a). Transnacionalização e mercadorização da educação superior: Examinando alguns efeitos colaterais do capitalismo acadêmico (sem riscos) no Brasil-a expansão privado-mercantil. Revista Internacional de Educação Superior, 1(1), 86-102.

Azevedo, M. L. N. (2015b). Higher education and international organizations: Cold War, commodification, and the global field of power. In S. Tuleski (Ed.), Liberation psychology in Brazil (pp. 13-39). New York: Nova.

Azevedo, M. L. N. (2015c). Internacionalização ou transnacionalização da educação superior: Entre a formação de um campo social global e um mercado de ensino mundializado. Crítica Educativa, 1(1), 56-79.

Bernheim, C. T. (2009). Central America: Quality assurance and accreditation. In F. L. Segrera, C. Brock, \& J. D. Sobrinho (Eds.), Higher education in Latin America and the Caribbean 2008 (pp. 49-68). Caracas: UNESCO/IESALC.

Bolivarian Republic of Venezuela/Federative Republic of Brazil. (2005). Comunicado conjunto: Alianza estratégica Venezuela-Brasil. Caracas, 14 February.

Bolivarian Republic of Venezuela/Federative Republic of Brazil. (2008a). Comunicado conjunto. Recife, 26 March.

Bolivarian Republic of Venezuela/Federative Republic of Brazil. (2008b). Memorando de entendimiento entre el Ministerio del Poder Popular para la Educación Superior de la República Bolivariana de Venezuela (MPPES) y el Ministerio de Educación de la República Federativa de Brasil. Recife, 26 March.

Bolivarian Republic of Venezuela/Federative Republic of Brazil. (2008c). Entendimiento entre el Ministerio del Poder Popular para la Educación Superior de la República Bolivariana de Venezuela (MPPES) y la Fundación de Perfeccionamiento de Personal de Nivel Superior de la República Federativa de Brasil (CAPES). Recife, 26 March.

Bolivarian Republic of Venezuela/Federative Republic of Brazil. (2008d). Comunicado conjunto. Recife, 27 March.

Bolivarian Republic of Venezuela/Federative Republic of Brazil. (2008e). Comunicado conjunto. Caracas, 27 June.

Bolivarian Republic of Venezuela/Federative Republic of Brazil. (2009). Comunicado conjunto de los presidentes Hugo Chávez Frías y Luiz Inácio Lula da Silva, en ocasión del encuentro presidencial realizado en el Proyecto Agrario Socialista Plancie de Maracaibo. Maracaibo, 16 January.

Bolivarian Republic of Venezuela/Federative Republic of Brazil. (2010a). Acuerdo entre el gobierno de la República Bolivariana de Venezuela y el gobierno de la República Federativa del Brasil sobre localidades fronterizas vinculadas. Brasilia, 28 April.

Bolivarian Republic of Venezuela/Federative Republic of Brazil. (2010b). Acuerdo entre el gobierno de la República Bolivariana de Venezuela y el gobierno de la República Federativa del Brasil para el establecimiento de un régimen especial fronterizo. Caracas, 6 August.

Bolivarian Republic of Venezuela/Federative Republic of Brazil. (2014). IX reunión bilateral Brasil-Venezuela de los organismos nacionales competentes para la aplicación del acuerdo 
Thomas Muhr (2016) Higher Education. The International Journal of Higher Education Research doi: 10.1007/s10734-016-0017-9

The final publication is available at http://link.springer.com/article/10.1007/s10734-016-0017-9

de transporte internacional por carretera de pasajeros y carga. Santa Elena de Uairén, 25/26 March.

Brenner, N. (2004). New state spaces: Urban governance and the rescaling of the state. Oxford: Oxford University Press.

Briceño Ruiz, J. (2012). New left governments, civil society and constructing a social dimension in Mercosur. In B. Cannon \& P. Kirby (Eds.), Civil society and the state in left-led Latin America (pp. 173-186). London: Routledge.

Cabrera, A. (2009). Construcción del conocimiento desde la comunicación. Intercultural. experiencias en el proceso pedagógico desarrollado en la aldea indígena. Kamarata. Paper presented at the XXVII Congreso de la Asociación Latinoamericana de Sociología.

Asociación Latinoamericana de Sociología, Buenos Aires, 2009.

http://www.aacademica.com/000-062/2272. Accessed September 6, 2015.

Dale, R. (1997). The state and the governance of education: An analysis of the restructuring of the state-education relationship. In A. H. Halsey, H. Lauder, P. Brown, \& A. S. Wells (Eds.), Education. Culture, economy, society (pp. 273-282). Oxford: Oxford University Press.

Dale, R. (2005). Globalisation, knowledge economy and comparative education. Comparative Education, 41(2), 117-149.

dos Santos, S. A. (2014). Affirmative action and political dispute in today's Brazilian academe. Latin American Perspectives, 41(5), 141-156.

Duffy, M. (2014). Education, democracy and social change: Venezuela's education missions in theory and practice. Journal of Education Policy, 30(5), 650-670.

Federative Republic of Brazil. (2007a). Politica nacional de desenvolvimento regional (sumário executivo). Brasilia: Ministério da Integração Nacional.

Federative Republic of Brazil. (2007b). The plan for the development of education. Reasons, principles and programs. Brasilia: Ministerio da Educação.

Ferraro, D. (2013). Políticas e iniciativas en MERCOSUR en el ámbito de la integración fronteriza, SP/XXIV-RDCIALC/Di No. 14-13. Caracas: SELA.

Gomes, A. M., Robertson, S. L., \& Dale, R. (2014). Globalizing and regionalizing higher education in Latin America. In D. Araya \& P. Marber (Eds.), Higher education in the global age. Policy, practice and promise in emerging societies (pp. 160-183). London: Routledge.

González Silva, H. J. (2009). Higher education in the Bolivarian revolution. In F. L. Segrera, C. Brock, \& J.D. Sobrinho (Eds.), Higher education in Latin America and the Caribbean 2008 (pp. 157-186). Caracas: UNESCO/IESALC.

Griffiths, T. (2013). Higher education for socialism in Venezuela: Massification, development and transformation. In T. G. Griffiths \& Z. Millei (Eds.), Logics of socialist education:

Engaging with crisis, insecurity and uncertainty (pp. 91-112). London: Springer.

Howitt, R. (1993). "A world in a grain of sand": Towards a reconceptualisation of geographical scale. Australian Geographer, 24(1), 33-44. 
Thomas Muhr (2016) Higher Education. The International Journal of Higher Education Research doi: 10.1007/s10734-016-0017-9

The final publication is available at http://link.springer.com/article/10.1007/s10734-016-0017-9

Howitt, R. (1998). Scale as relation: Musical metaphors of geographical scale. Area, 30(1), $49-58$.

INEP. (2013). Censo da educação superior 2013. Instituto Nacional de Estudos e Pesquisas Educacionais.

http://download.inep.gov.br/educacao_superior/censo_superior/apresentacao/2014/coletiva_c enso_superior_2013.pdf. Accessed September 8, 2015.

Instituto Social del MERCOSUR. (2015). Economía social y solidaria-resumen.

http://ismercosur.org/proyectos/economia-social-y-solidaria/. Accessed June 2, 2014.

Mansfield, B. (2005). Beyond rescaling: Reintegrating the 'national' as a dimension of scalar relations. Progress in Human Geography, 29(4), 458-473.

Marston, S. A., \& Smith, N. (2001). States, scales and households: Limits to scale thinking? A response to Brenner. Progress in Human Geography, 25(4), 615-619.

Martinez, M. V. (2009). Redes urbanas transfronterizas: Dos escenarios venezolanos. Aldea Mundo. Revista sobre Fronteras e Integración, 14(27), 7-15.

McCowan, T. (2007). Expansion without equity: An analysis of current policy on access to higher education in Brazil. Higher Education, 53(5), 579-598.

McCowan, T. (2015). Three dimensions of equity of access to higher education. Compare: A Journal of Comparative and International Education, 45(5), 792-813.

MERCOSUR. (2000). Plan estratégico 2001-2005. http://www.sic.inep.gov.br/esES/documentoscategoria/finish/7-planos-planes/411-plano-2001-2005.html.

MERCOSUR. (2005). Plan del sector educativo del MERCOSUR 2006-2010. http://www.sic.inep.gov.br/es-ES/documentos-categoria/finish/7-planos-planes/412-plano2006-2010.html.

MERCOSUR. (2006). Declaración final. Brasilia, 14 December.

MERCOSUR. (2007). XXXII Reunión de ministros de educación de los países del MERCOSUR. MERCOSUR/XXXII RME/ACTA No. 01/07, 1 June.

MERCOSUR. (2011). Plan de acción del sector educativo del MERCOSUR 2011-2015. http://www.sic.inep.gov.br/es-ES/component/jdownloads/finish/7/414.html.

MERCOSUR. (2012a). Plan estratégico de acción social. Asunción: Instituto Social del MERCOSUR.

MERCOSUR. (2012b). Comunicado conjunto de los presidentes de los estados partes del MERCOSUR. Mendoza, 29 June.

MERCOSUR. (2012c). Comunicado conjunto de los presidentes de los estados partes del MERCOSUR. Brasilia, 7 December.

MINCI. (2004). Desarrollo endógeno. Desde adentro, desde la Venezuela profunda. Caracas: Ministerio de Comunicación e Información. 
Thomas Muhr (2016) Higher Education. The International Journal of Higher Education Research doi: 10.1007/s10734-016-0017-9

The final publication is available at http://link.springer.com/article/10.1007/s10734-016-0017-9

MPPEU. (2012). Logros de la educación universitaria 2012. Caracas: Ministerio del Poder Popular para la Educación Universitaria.

MPPEU. (2014). Memoria 2013. Caracas: Ministerio del Poder Popular para la Educación Universitaria.

MPPEU. (2015). Memoria y cuenta. Caracas: Ministerio del Poder Popular para la Educacioón Universitaria.

Muhr, T. (2010). Counter-hegemonic regionalism and higher education for all: Venezuela and the ALBA. Globalisation, Societies and Education, 8(1), 39-57.

Muhr, T. (2011). Venezuela and the ALBA: Counter-hegemony, geographies of integration and development, and higher education for all. Saarbrücken: VDM.

Muhr, T. (2013). Rivalry or cooperation? The ALBA-TCP, UNASUR, and Brazil-Venezuela sub-regionalism. Paper presented at the ISA CISS with UNU-CRIS, Bruges, Belgium, 19 June 2013. http://www.academia.edu/attachments/32240985/download file.

Muhr, T. (2015a). South-South cooperation in education and development: the ;Yo, Si Puedo! literacy method. International Journal of Educational Development, 43, 126-133.

Muhr, T. (2015b). The ALBA-TCP: Setting the standards for a Latin American and Caribbean South-South cooperation space? Paper presented at the XXXIII LASA Congress, San Juan, May 29.

Muhr, T. (2016a). Beyond 'BRICS': Ten theses on South-South cooperation in the 21st century. Third World Quarterly, 37(4), 630-648. doi:10.1080/01436597.2015.1108161.

Muhr, T. (2016b). South-South development cooperation and the socio-spatial reconfiguration of Latin America-Caribbean regionalisms: University education in the BrazilVenezuela 'Special Border Regime'. In S. L. Robertson, K. Olds, R. Dale, \& Q. A. Dang (Eds.), Global regionalisms and higher education: Projects, processes, politics. Cheltenham: Edward Elgar.

Muhr, T., \& Verger, A. (2006). Venezuela: Higher education for all. The Journal for Critical Education Policy Studies, 4(1), 160-194.

OPSU. (2015). Sistema Nacional de Ingreso. Oficina de Planificación del Sector Universitario. http://ingreso.opsu.gob.ve/. Accessed September 6, 2015.

Paasi, A. (2004). Place and region: Looking through the prism of scale. Progress in Human Geography, 28(4), 536-546.

Presidência da República. (2003). Decreto no. 4.793, 23 July.

Presidência da República. (2005). Lei no. 11.096, 13 January.

Presidência da República. (2007). Decree no. 6.047, 22 February.

Presidência da República. (2012). Lei no. 12.711, 29 August. 
Thomas Muhr (2016) Higher Education. The International Journal of Higher Education Research doi: $10.1007 /$ s10734-016-0017-9

The final publication is available at http://link.springer.com/article/10.1007/s10734-016-0017-9

Presidência da República. (2014). Lei no. 13.005, 25 June.

RBV. (2001). Líneas generales del plan de desarrollo económico y social de la nación, 20012007. Caracas: República Bolivariana de Venezuela.

RBV. (2007). Líneas generales del plan de desarrollo económico y social de la nación, 20072013. Caracas: República Bolivariana de Venezuela.

Robertson, S., \& Dale, R. (2013). The social justice implications of privatisation in education governance frameworks: A relational account. Oxford Review of Education, 34(9), 426-445.

Sá e Silva, M. M. (2009). South-South cooperation: past and present. Conceptualization and practice. In L. Chisholm \& G. Steiner-Khamsi (Eds.), South-South cooperation in education and development (pp. 39-59). New York: Teachers College Press.

Sobrinho, J. D., \& Ferreira de Brito, M. R. (2009). Higher education in Brazil: Main trends and challenges. In F. L. Segrera, C. Brock, \& J. D. Sobrinho (Eds.), Higher education in Latin America and the Caribbean 2008 (pp. 235-253). Caracas: UNESCO/IESALC.

Smith, N. (1992). Contours of a spatialized politics: Homeless vehicles and the production of geographical scale. Social Text, 33, 54-81.

Sunkel, O. (Ed.). (1993). Development from within. London: Lynne Rienner.

Swyngedouw, E. (1997). Neither global nor local: "glocalization" and the politics of scale. In K. R. Cox (Ed.), Spaces of globalization. Reasserting the power of the local (pp. 137-166). New York: Guildford.

Toro, L. F. (2004). La aldea universitaria bolivariana. Paginadigital, 29 October. http://www.paginadigital.com.ar/articulos/2004/2004cuart/educacion/e1422610-4.asp. Accessed October 2, 2015.

Toro, L., Marín, M., Silvera, F., \& Jaimes, J. (2009). Deserción estudiantil en la Misión Sucre. Educere, 12(46), 751-769.

UIS. (2010). Global education digest 2010. Montreal: UNESCO Institute for Statistics.

UIS. (2015a). Statistical tables. Education: Gross enrolment ratio by level of education. http://data.uis.unesco.org/index.aspx?queryid=142\&amp;lang=en. Accessed September 5, 2015.

UIS. (2015b). Statistical tables. Education: Distribution of enrolment by type of institution. http://data.uis.unesco.org/index.aspx?queryid=142\&amp;lang=en. Accessed September 5, 2015.

UNESCO. (2014). BRICS. Building education for the future. Priorities for national development and international cooperation. Paris: UNESCO.

UNESCO-IESALC. (2008). Entrevista a Bernardo Ancidey. Boletín Digital. http://150.185.8.110/previo/docs/boletines/boletinnro166/boletinnro166.html. Accessed $28 / 08 / 2015$. 